\title{
Effects of blood storage on ice in biochemical and arterial blood gas analysis of rats $^{1}$
}

\author{
Efeitos da estocagem sanguínea em gelo na bioquímica e gasometria arterial de ratos
}

\author{
Marcus Vinicius Henriques Brito', Izabella Cristina Cristo Cunha', Mayra Gonçalves Aragón", Thiago Gabbay Martins Braga"I, \\ Fabrício Diniz de Lima ${ }^{I I}$
}

${ }^{\text {I }} \mathrm{PhD}$, Associate Professor, Head of Operative Technique, Experimental Surgery and Anesthesiology Division, UEPA, Brazil.

${ }^{\text {II } G r a d u a t e ~ s t u d e n t ~ o f ~ M e d i c i n e, ~ U E P A, ~ B r a z i l . ~}$

\begin{abstract}
Purpose: To investigate the effects of blood storage in biochemical and arterial blood gas analysis of Wistar rats. Methods: Ten adult male rats with weights between 300-350 g were used. The catheterization of the internal carotid artery were performed, followed by withdrawal of $3 \mathrm{ml}$ of blood using 3 separate syringes each containing $1 \mathrm{ml}$. The syringes were fulfilled one after another and numerated according to the order of collection. Then, the following groups were devised: GT1 - samples that were firstly analyzed in 20 minutes and the second exam 65 minutes after the collection; GT2 - samples that were firstly analyzed in 35 minutes and the second exam 80 minutes after the collection; GT3 - samples that were firstly analyzed in 50 minutes and the second exam 95 minutes after the collection. The samples were stored in a container with a temperature between $0 \mathrm{C}^{\mathrm{o}}$ and $4 \mathrm{C}^{\mathrm{o}}$. Upon analysis the values of $\mathrm{pH}, \mathrm{PaCO}_{2}, \mathrm{PaO}_{2}, \mathrm{HCO}_{3}^{-}$, $\mathrm{SatO}_{2}, \mathrm{SBE}, \mathrm{Na}^{+}$and $\mathrm{K}^{+}$concentrations and glucose were compared. Results: No statistically relevant difference ( $\mathrm{p}<0.05$ ) between the GT1, GT2 or GT3, when measuring $\mathrm{pH}, \mathrm{PaCO}_{2}, \mathrm{PaO}_{2}, \mathrm{HCO}_{3}^{-}, \mathrm{SatO}_{2}, \mathrm{SBE}$ or glucose, were found. However, $\mathrm{Na}^{+}$concentration decreased and the $\mathrm{K}^{+}$concentration increased $(\mathrm{p}<0.05)$ when comparing the first analysis (20 minutes) with the last one $(95$ minutes). Conclusion: The blood storage on ice does not interfere in the results of arterial blood gas analysis for the period of at least 95 minutes, except for the $\mathrm{Na}^{+}$e $\mathrm{K}^{+}$levels, which are practicable until 80 minutes after storage.
\end{abstract}

Key words: Blood Preservation. Blood Gas Analysis. Rats.

\section{RESUMO}

Objetivo: Analisar o efeito da estocagem sanguínea na bioquímica e na gasometria do sangue arterial de ratos Wistar. Métodos: Foram utilizados 10 ratos adultos, machos, com peso compreendido entre 300 a 350 gramas. Cada animal foi submetido à cateterização da artéria carótida seguida de heparinização prévia do animal. Foram colhidos $3 \mathrm{ml}$ de sangue total do rato, separados em três seringas contendo $1 \mathrm{ml}$ cada. As seringas foram preenchidas uma após a outra e enumeradas respectivamente à ordem de coleta. De acordo com esta numeração as amostras foram distribuídas nos seguintes grupos: GT1 - amostras que tiveram primeira análise em 20 minutos e a segunda análise 65 minutos após a coleta; GT2 - amostras que tiveram primeira análise em 35 minutos e segunda análise 80 minutos após a coleta; GT3 - amostras que tiveram primeira análise em 50 minutos e 95 minutos após a coleta. As amostras foram estocadas em material isolante térmico, com temperatura entre $0 \mathrm{C}^{\circ}$ e $4 \mathrm{C}^{\circ}$. Foram comparados os valores de $\mathrm{pH} \mathrm{PaCO}_{2}, \mathrm{PaO}_{2}, \mathrm{HCO}_{3}^{-}, \mathrm{SatO}_{2}, \mathrm{SBE}_{\text {, }}$ concentrações de $\mathrm{Na}^{+}$e $\mathrm{K}^{+}$e glicose. Resultados: Não foram encontradas diferenças estatisticamente significantes (p<0.05) entre GT1, GT2 ou GT3 quando medidos $\mathrm{pH}, \mathrm{PaCO}_{2}, \mathrm{PaO}_{2}, \mathrm{HCO}_{3}{ }^{-}, \mathrm{SatO}_{2}, \mathrm{SBE}$ ou glicose. Entretanto, a concentração de $\mathrm{Na}^{+}$apresentou decréscimo enquanto que a concentração de $\mathrm{K}^{+}$aumentou $(\mathrm{p}<0.05)$ quando comparados a primeira análise $(20$ minutos $)$ e a última análise (95 minutos). Conclusão: A estocagem sanguínea em gelo não interfere nos resultados gasométricos arteriais no período mínimo de 95 minutos, à exceção dos níveis de $\mathrm{Na}^{+}$e $\mathrm{K}^{+}$, viáveis até 80 minutos de análise pós-estocagem.

Descritores: Preservação de Sangue. Gasometria. Ratos.

${ }^{1}$ Research performed at Experimental Surgery Laboratory, State University of Pará (UEPA), Belém - PA, Brazil.

\section{Introduction}

The arterial blood gas analysis and the electrolytes measure are important laboratorial exams for characterization and hydroelectrolytic and acid-base disequilibrium intensity evaluation ${ }^{1}$.

It is even more diffused the idea to realize a laboratorial procedure in the shortest time interval possible after the sample collection. However, in numerous practical daily situations an immediate analysis of the collected blood is not feasible, and thus storage of the sample is necessary ${ }^{2,3}$. In this case, adequate storage implies that the examing results and consequently the analysis, diagnostic and the prescribed treatment must not be influenced by the storage time indicated ${ }^{3}$. 
The inadequate handling and usage of material is one of the main causes for errors in blood gas analysis ${ }^{2,3}$, errors that can lead to false results ${ }^{3}$.

The possibility of blood samples maintenance at low temperatures is an object of interest in some scientific researches which make use of bovine ${ }^{2,4,5,6}$, equine $e^{5,7,8}$, canine ${ }^{9}$ and porcine $^{10}$ species. However, there is a lack of consensus in literature regarding the maximum amount of time blood samples can be stored for blood gas analysis at low temperatures.

Considering the definition of the viability of considerable storage time in arterial blood gas analysis, the objective being the analysis of blood samples stored on ice at different intervals of time.

\section{Methods}

All the animals used in this research were treated with the respect of the National Legislation for Animal Vivisection which works nowadays (Federal Law 6,638 since May $8^{\text {th }}, 1979$ ) and respecting the rules from the Brazilian School for Experimental Surgery (COBEA). This research has been approved by the Research Ethical Committee from State University of Pará (UEPA), by the Nucleus for Medical Research \& Extension (NUPEM) and by the Head of the Experimental Surgery Laboratory (LCE) from UEPA.

In this study ten rats (Rattus novergicus albinus, Rodentia, Mammalia) were used, Wistar, males, adults, with individual weights varying between 300 and 350 grams, originating from the Biotério do Instituto Evandro Chagas (Belém-Pará). All the procedures were made at the Laboratório de Cirurgia Experimental do Centro de Ciências Biológicas e da Saúde da Universidade do Estado do Pará after a period of 15 days to acclimate.

The rats were kept in an acclimatized room with a temperature of $22^{\circ} \mathrm{C}$ in plastic cages, regularly cleaned and changed according to the regulations of the Colégio Brasileiro de Experimentação Animal. The water and food were provided ad libitum during the entire experiment.

The animals were anesthetized prior to the surgical intervention and the collection of blood. The animals were anesthetized by the means of continuous inhalation of ethylic ether ${ }^{11}$.

Each animal was firstly immobilized on the surgical plate in dorsal decubitus position, then a paramedian cervical incision was made, followed by the catheterization of the internal carotid artery ${ }^{12}$.

A P-50 catheter, siliconyzed, with a diameter of $0.5 \mathrm{~mm}$ was used.

Immediately after the introduction and fixation of the catheter, from a solution of $1 \mathrm{ml}$, containing $0,03 \mathrm{ml}$ of Sodium Heparine $5000 \mathrm{U}$ and $0.97 \mathrm{ml}$ of physiological serum $0.9 \%$ (quantity needed to $100 \mathrm{~mL}$ ), $0.4 \mathrm{ml}$ were used to heparinize the catheter, while $0.6 \mathrm{ml}$ was used to heparinize the animal. This was followed by the collection of the blood samples using three syringes that were immediately put in a thermal container fulfilled by ice and ice bags with a temperature ranging from $0^{\circ} \mathrm{C}$ to $4^{\circ} \mathrm{C}$. The samples were positioned and immobilized above the ice bags in order to prevent the freezing of the blood.

The air bubbles of the collected blood samples were immediately removed and after was injected a small quantity of blood in the distal extremity of the needle in order to avoid the exchange of gases with the environmental air.
The $3 \mathrm{ml}$ of blood obtained from each animal was collected using 3 previously heparinized syringes, each collection being made immediately after the previous one. A number was assigned to each syringe (the first sample was labeled I, the second II and the third III) and according to this labeling the samples were distributed in the following groups:

GT1 (Group T1): samples which were analyzed firstly after 20 minutes from collection and secondly 45 minutes after the first exam.

GT2 (Group T2): samples which were analyzed firstly after 35 minutes from collection and secondly 45 minutes after the first exam.

GT3 (Group T3): samples which were analyzed firstly after 50 minutes from collection and secondly 45 minutes after the first exam.

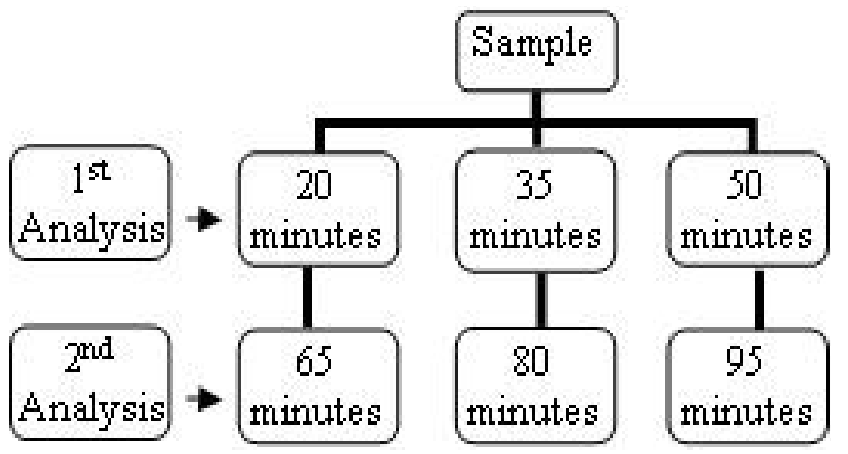

According with the time intervals when the blood samples were analysed, the following periods were assigned:

$\mathrm{T}_{0}$ : The time when the samples were collected

$\mathrm{T}_{1}: 20$ minutes after $\mathrm{T}_{0}$; the $1^{\text {st }}$ analysis of sample $\mathrm{I}$

$\mathrm{T}_{2}: 35$ minutes after $\mathrm{T}_{0}$; the $1^{\text {st }}$ analysis of sample II

$\mathrm{T}_{3}: 50$ minutes after $\mathrm{T}_{0}$; the $1^{\text {st }}$ analysis of sample III

$\mathrm{T}_{4}: 65$ minutes after $\mathrm{T}_{0}$; the $2^{\text {nd }}$ analysis of sample I

$\mathrm{T}_{5}: 80$ minutes after $\mathrm{T}_{0}$; the $2^{\text {nd }}$ analysis of sample II

$\mathrm{T}_{6}: 95$ minutes after $\mathrm{T}_{0}$; the $2^{\text {nd }}$ analysis of sample III

The analysis were made using the same $\mathrm{pH}$ and blood gases analyzer (gasometer) Radioemter ${ }^{\circledR}$, in order to obtain the values for arterial $\mathrm{pH}$, partial $\mathrm{CO}_{2}$ arterial pressure $\left(\mathrm{PaCO}_{2}\right)$, partial oxygen arterial pressure $\left(\mathrm{PaO}_{2}\right)$, oxygen saturation $\left(\mathrm{SatO}_{2}\right)$, Standard Base Excess $(\mathrm{SBE}), \mathrm{HCO}_{3}{ }^{-}$values $\left(\mathrm{HCO}_{3}^{-}\right)$, concentration of sodium ions $\left(\mathrm{Na}^{+}\right)$, concentration of potassium ions $\left(\mathrm{K}^{+}\right)$and concentration of glucose.

The syringes were homogenized shortly before being positioned normally regarding the hatch of the analyzer and the needed quantity of blood was rapidly injected in order to prevent the entrance of air within the syringe.

The results were fulfilled on the research protocol and after submitted to statistical analysis through the variance verifying by the Kruskal-Wallis test, admitting the alpha level $\alpha=0,05(5 \%)$ and making use of the BioEstat 3.0 software. 


\section{Results}

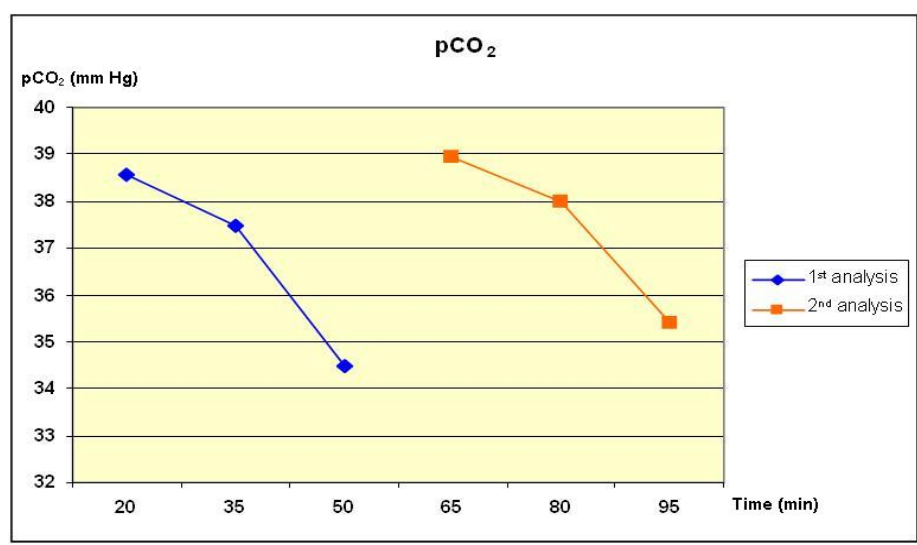

FIGURE $1-\mathrm{pCO}_{2}$ average values in the first and second gasometrical analysis during the blood storage on ice

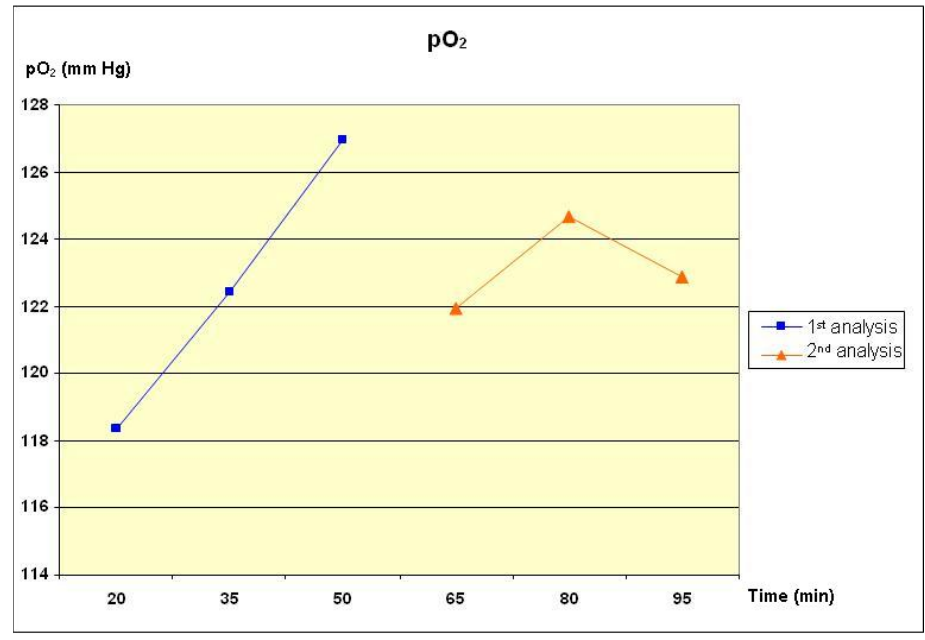

FIGURE $2-\mathrm{pO}_{2}$ average values in the first and second gasometrical analysis during the blood storage on ice

TABLE $1-\mathrm{Na}^{+}$values in the first and second gasometrical analysis during the blood storage on ice

\begin{tabular}{|c|c|c|c|c|c|c|}
\hline & \multicolumn{3}{|c|}{$1^{\text {st }}$ Analysis } & \multicolumn{3}{|c|}{$2^{\text {nd }}$ Analysis } \\
\hline Time analysis & $20 \mathrm{~min}$ & $35 \mathrm{~min}$ & $50 \mathrm{~min}$ & $65 \mathrm{~min}$ & $80 \mathrm{~min}$ & $\begin{array}{c}95 \\
\text { min }^{*}\end{array}$ \\
\hline R1 & 142 & 141 & 139 & 143 & 141 & 138 \\
\hline $\mathrm{R} 2$ & 141 & 143 & 140 & 140 & 144 & 140 \\
\hline $\mathrm{R} 3$ & 144 & 149 & 139 & 143 & 149 & 139 \\
\hline $\mathrm{R} 4$ & 145 & 143 & 143 & 144 & 142 & 141 \\
\hline R5 & 141 & 142 & 140 & 141 & 141 & 139 \\
\hline R6 & 143 & 140 & 140 & 142 & 139 & 140 \\
\hline R7 & 145 & 144 & 144 & 144 & 143 & 143 \\
\hline R8 & 145 & 142 & 143 & 144 & 142 & 141 \\
\hline R9 & 144 & 141 & 140 & 143 & 141 & 140 \\
\hline R10 & 147 & 145 & 143 & 147 & 144 & 143 \\
\hline Averages & 143.7 & 143.0 & 141.1 & 143.1 & 142.6 & 140.4 \\
\hline
\end{tabular}

$\mathrm{p}<0.05^{*}$ (Kruskal-Wallis) 


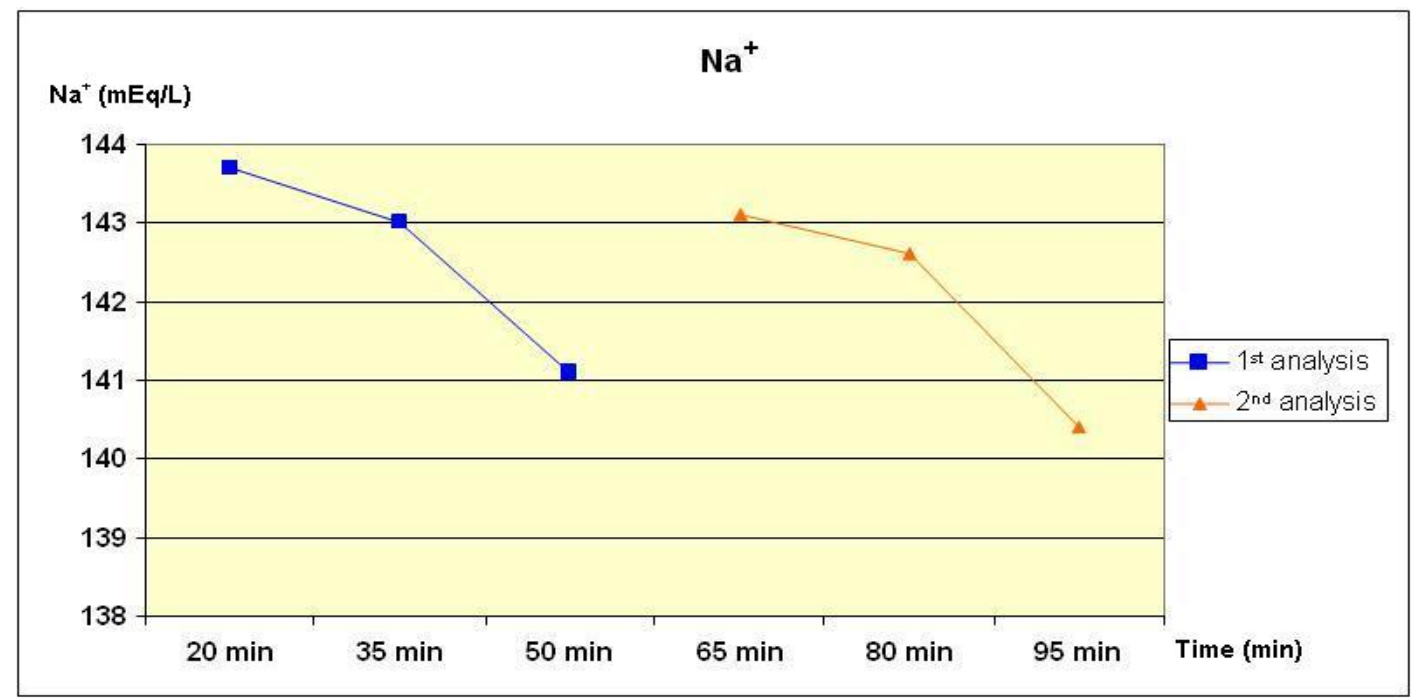

FIGURE $3-\mathrm{Na}^{+}$average values in the first and second gasometrical analysis during the blood storage on ice

TABLE $2-\mathrm{K}^{+}$values in the first and second gasometrical analysis during the blood storage on ice.

\begin{tabular}{c|c|c|c|c|c|c}
\hline & \multicolumn{3}{|c|}{$1^{\text {st }}$ Analysis } & \multicolumn{3}{c}{$2^{\text {nd }}$ Analysis } \\
\hline Time analysis & $\mathbf{2 0} \mathbf{~ m i n}$ & $\mathbf{3 5} \mathbf{~ m i n}$ & $\mathbf{5 0} \mathbf{~ m i n}$ & $\mathbf{6 5} \mathbf{~ m i n}$ & $\mathbf{8 0 ~ \mathbf { ~ m i n }}$ & $\begin{array}{c}\mathbf{9 5} \\
\text { min }\end{array}$ \\
\hline R1 & 3.1 & 3.0 & 3.2 & 3.1 & 3.1 & 3.3 \\
\hline R2 & 3.2 & 3.3 & 3.2 & 3.3 & 3.4 & 3.4 \\
\hline R3 & 2.7 & 2.9 & 3.4 & 3.0 & 3.1 & 3.5 \\
\hline R4 & 2.7 & 2.9 & 3.2 & 2.8 & 3.1 & 3.3 \\
\hline R5 & 3.0 & 3.0 & 3.4 & 3.3 & 3.3 & 3.5 \\
\hline R6 & 3.5 & 3.7 & 3.8 & 3.7 & 3.9 & 4.0 \\
\hline R7 & 3.3 & 3.4 & 3.7 & 3.5 & 3.7 & 4.0 \\
\hline R8 & 3.0 & 3.4 & 3.8 & 3.3 & 3.7 & 4.0 \\
\hline R9 & 3.1 & 3.8 & 3.7 & 3.3 & 4.0 & 3.9 \\
\hline R10 & 3.2 & 3.4 & 3.6 & 3.4 & 3.6 & 3.7 \\
\hline Averages & $\mathbf{3 . 0 8}$ & $\mathbf{3 . 2 8}$ & $\mathbf{3 . 5 0}$ & $\mathbf{3 . 2 7}$ & $\mathbf{3 . 4 9}$ & $\mathbf{3 . 6 6}$ \\
\hline R & & & &
\end{tabular}

$\mathrm{p}<0.05^{*}$ (Kruskal-Wallis) 


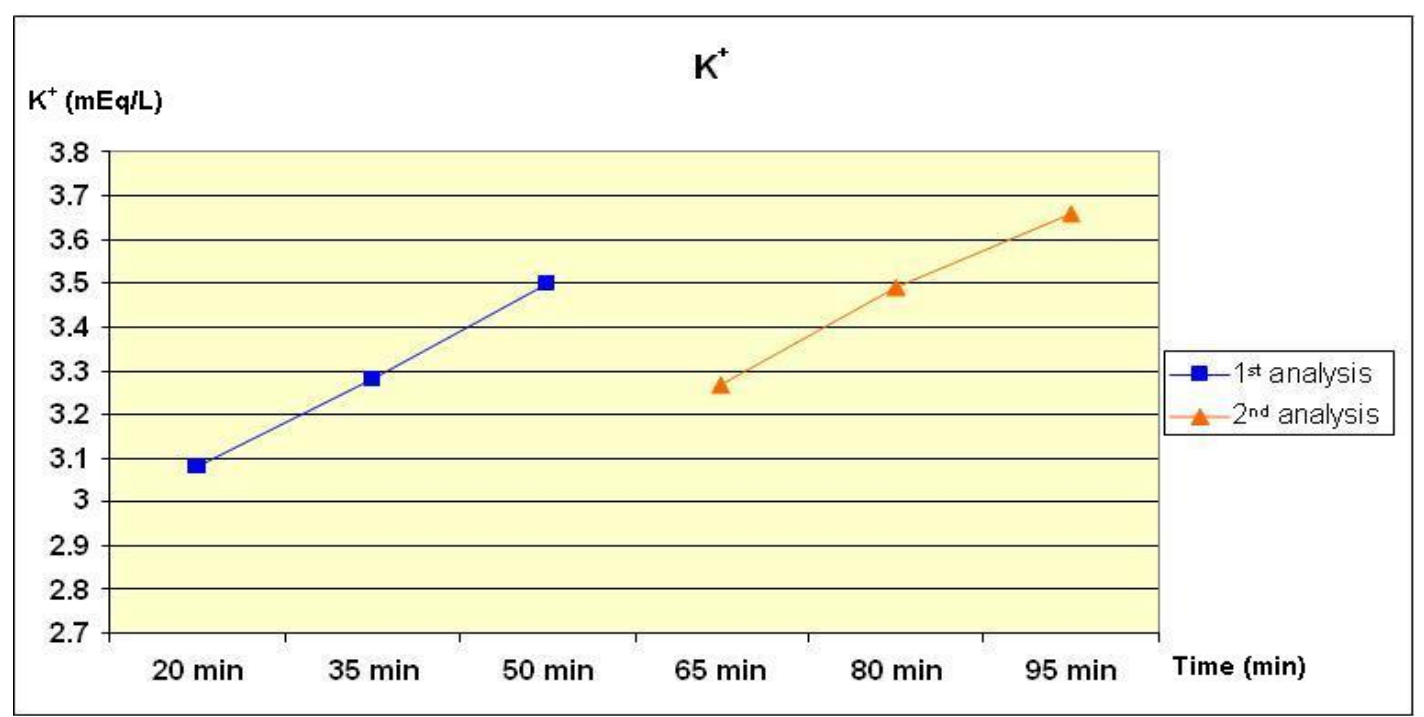

FIGURE $4-\mathrm{K}^{+}$average values in the first and second gasometrical analysis during the blood storage on ice

TABLE 3 - Average values of all variables in the first and second gasometrical analysis during the blood storage on ice

\begin{tabular}{c|c|c|c|c|c|c}
\hline & \multicolumn{3}{|c|}{$1^{\text {st }}$ Analysis } & \multicolumn{3}{c}{$2^{\text {nd }}$ Analysis } \\
\hline Time analysis & $\mathbf{2 0} \mathbf{m i n}$ & $\mathbf{3 5}$ min & $\mathbf{5 0}$ min & $\mathbf{6 5}$ min & $\mathbf{8 0 ~ m i n}$ & $\mathbf{9 5}$ min \\
\hline $\mathrm{pH}$ & 7.3326 & 7.3492 & 7.3715 & 7.3310 & 7.3418 & 7.3617 \\
\hline $\mathrm{pCO}_{2}$ & 38.58 & 37.48 & 34.47 & 38.94 & 37.98 & 35.42 \\
\hline $\mathrm{pO}_{2}$ & 118.37 & 122.42 & 126.97 & 121.95 & 124.66 & 122.89 \\
\hline $\mathrm{HCO}_{3}^{-}$ & 19.67 & 19.38 & 18.99 & 19.86 & 19.38 & 19.1 \\
\hline $\mathrm{SBE}$ & -5.33 & -5.31 & -5.13 & -5.07 & -5.42 & -5.4 \\
\hline $\mathrm{Sat} \mathrm{O}_{2}$ & 96.16 & 97.67 & 97.5 & 96.77 & 97.81 & 97.4 \\
\hline $\mathrm{Na}^{+}$ & 143.7 & 143 & 141.1 & 143.1 & 142.6 & 140.4 \\
\hline $\mathrm{K}^{+}$ & 3.08 & 3.28 & 3.5 & 3.27 & 3.49 & 3.66 \\
\hline $\mathrm{Glicose}^{+}$ & 248.1 & 259.1 & 275 & 247.7 & 257 & 273.9 \\
\hline
\end{tabular}

$\mathrm{p}=0.9999$ (Kruskal-Wallis) 


\section{Discussion}

The acid-base state of an organism is clinically evaluated through the analysis of the arterial blood gas analysis parameters. Thus, this exam is such important to diagnose with accuracy the acid-base abnormalities, just as it can be applied to humans and to experimental surgery ${ }^{3}$.

It is necessary various precautions with the sample collected, since the collection until the analysis method, which can change, between another factors, the result trustworthiness ${ }^{2}$. The shortest time between the sample collection and its analysis is emphasized in the literature, purposing an ideal analysis. In front of the difficulties in the practical clinics and the limitations that can be placed against that, is indispensable to store the blood on ice. Although, there is a lack of consensus in literature regarding the amount of time blood samples can be feasible and if that storage is really effective $\mathrm{e}^{3,4,6,7,9,10}$

The samples were collected at the same moment and analyzed in different times: 20 minutes, 35 minutes and 50 minutes. Then, the analysis of each group was repeated 45 minutes after the first.

In the first place, the statistical analysis was made comparing the degree of variance regarding the same blood sample between the first and the second analysis. So, it was analyzed respectively the group 20 and 65 minutes; 35 and 80 minutes; 50 and 95 minutes. No results were statistically significant. After, the blood samples were compared between itself to determine the possible difference caused by its collection or storage. It was not observed statistical differences in any group about the $\mathrm{pH}, \mathrm{PCO}_{2}$, $\mathrm{PO}_{2}, \mathrm{O}_{2}$ Saturation, SBE, Glucose and $\mathrm{HCO}_{3}^{-}$.

It evinces that, when the blood samples are stored between $0^{\circ} \mathrm{C}$ and $4^{\circ} \mathrm{C}$, there are minimal variations, which are not capable to modify significantly the blood gas analysis results. Hence, the basal levels of metabolism are maintained.

The metabolism maintenance would be made by a mechanism of inhibition of the sodium-potassium pump, thus the sample cooling between $0^{\circ} \mathrm{C}$ and $4^{\circ} \mathrm{C}$ is indicate, because it could reduce 10 times the metabolism ${ }^{2}$. The $\mathrm{pH}$ level continued constant, with a discreet decrease, which does not evidence statistical difference $(p=0,5967)$. Agreeing the literature, there is a tendency to reduce the $\mathrm{pH}$ values when the metabolism keep itself without pulmonary gas exchange, manifesting an acidosis ${ }^{2,3}$ and it was verified.

The $\mathrm{O}_{2}$ saturation, refereed by Gokce et $a .^{2}$ as decreasing to temperatures of $37^{\circ} \mathrm{C}$, exposed in a first moment an increase and after its values were declined. Normally, the first sample collected has most contact with the environmental air through the syringe during the collection, while the posterior samples which have the catheter fulfilled of blood are gradually more protected against the environmental air.

That contact of the first samples with the external air would be the responsible of the different $\mathrm{pO}_{2}$ values that were found. In despite of the statistical differences do not be significant to $\mathrm{pO}_{2}$, its values, in general, were crescent, as reported Lisboa et al. ${ }^{6}$. That values normally reduce, because the oxygen consumed into the cellular metabolism is not restored ${ }^{2}$, disagreeing with the results of this study, which have the $\mathrm{pO}_{2}$ values lessened only in the third samples, that was stored during 50 minutes and was analysed again in the $90^{\text {th }}$ minute. That can be attributed for the initial tendency of oxygen in to get up the concentration though a initial diffusion.
However, seeing the cell's necessities, its values would diminish suddenly. Another hypothesis is a diffusion of that gas through the syringe, which is made by plastic material and allows lowermost gases exchanges, but that are existent. Further, another explanation is justified in the idea the sample temperature in the homogenization, which is made before the analysis using the gasometer, is lower according the collection order, not having enough time to the adequate sample cooling of the first samples collected. Then, that homogenization, when is done near to the environmental temperature, there will be more gas diffusion, which is detected by the gasometer.

The $\mathrm{pCO}_{2}$ and the glucose do not revealed significant alteration of the values, demonstrating increase and progressive decreasing, respectively, corroborating with previous researches ${ }^{2,3,6}$. In this manner, the $\mathrm{CO}_{2}$ released by the cellular metabolism would have its values raised, while the glucose would present gradually lower amounts, because it is consumed. It neither was observed significant variations of bicarbonate, which had reduction rate, whereas is consumed when the anaerobiosis is installed.

Among all the variables analysed in this study, only the sodium and potassium ions presented statistical differences ( $\mathrm{p}<0,05$, Kruskal-Wallis), when were compared the first analysis values of the Group $\mathrm{T}_{1}$ with the second analysis of the Group $\mathrm{T}_{3}$. Even thus, the comparison between the first and the second analysis of samples did not present statistical differences, confirming the storage efficacy.

To analyze the sodium and potassium levels it is recommended the sample is stored in a maximum period of 30 minutes, because can occur failures due to the inhibited sodium-potassium pump, which is more vulnerable to changes ${ }^{2}$. In this study, it was found out a feasibility of 80 minutes to evaluation of those values.

Hence, it was evinced the low temperatures are important to conserve feasible a sample stored, enabling a permissive factor to the most sample duration without result alterations. Nevertheless, the most is the sample storage the most are the subjections to modifications, therefore is necessary more researches about this subject. The sample cooling does not stop the cellular metabolism, working as an excellent resource to its speed reduction. The importance of performing the blood analysis as soon as possible according the chances must not be excluded and it is such important to follow the basic principles of collection. The adequate storage and its time provide a longer viability duration.

\section{Conclusion}

It was verified that the blood storage on ice does not modify the results of the arterial blood gas analysis into the period of 95 minutes, except the $\mathrm{Na}^{+}$and $\mathrm{K}^{+}$levels, which are feasible until 80 minutes of analysis.

\section{References}

1. Johnson, PJ. Electrolyte and acid-base disturbances in the horse. Vet Clin North Am Equine Pract. 1995;11:491-514.

2. Gokce G, Citil M, Gunes V, Atalan G. Effect of time delay and storage temperature on blood gas and acid-base values of bovine venous blood. Res Vet Sci. 2004;76(2):121-7.

3. Yen CC, Vragas FA, Cukier A, Terra Filho M, Romeiro Neto M. Influência da estocagem do sangue arterial nas dosagens gasométricas. Rev Bras Clín Ter. 1985;14(8):271-4. 
4. Szenci O, Besser T. Changes in blood gas and acid-base values of bovine venous blood during storage. J Am Vet Med Assoc. 1990;197:471-4. 5. Szenci O, Brydl E, Bajcsy CA. Effect of storage on measurement of ionized calcium and acid-base variables in equine, bovine, ovine, and canine venous blood. J Am Vet Med Assoc. 1991;199:1167-9.

6. Lisboa JAN, Benesi FJ, Maruta CA, Mirandola RMS, Teixeira CMC. Tempo de viabilidade de amostras de sangue venoso bovino destinadas ao exame hemogasométrico, quando mantidas sob conservação em água gelada. Ciênc Rural. 2001;31(2):271-6.

7. Deane JC, Dagleish MP, Benamou AE, Wolf BT, Marlin D. Effects of syringe material and temperature and duration of storage on the stability of equine arterial blood gas variables. Vet Anaesth Analg. 2004;31(4):250-7.
8. Assal AN, Poulsen JS. Acid-base status of equine blood during storage. Nordisk Vet. 1978;30(9):354-63.

9. Assal AN, Arnbjerg J, Poulsen JSD. Acid-base statuts of canine blood during storage. Nordisk Vet. 1978;30:345-53.

10. Assal AN, Christiansen IJ, Poulsen JSD. Acid-base statuts of porcine blood during storage. Nordisk Vet. 1980;32:9-16.

11. Brito MVH, Brito NMB, Almeida AJB, Santos MRLC. Vaporizador artesanal de éter para cirurgia experimental em ratos. Acta Cir Bras. 1998;13(1):3-5.

12. Brito MVH, Maneschy RB, Albuquerque BCM, Araújo Júnior FA, Braz MN, Rocha Neto OG. Técnica de dissecção e cateterização da artéria carótida comum de ratos. Rev Para Med. 2004;18(1):36-41.

\section{Correspondence:}

Marcus Vinícius Henriques Brito

Av. Trav. Padre Eutíquio, 2264/1101

66033-000 Belém - PA Brazil

Phone: (55 91)3223-3609 / 9981-6321

mnbrito@amazon.com.br

Conflict of interest: none

Financial source: none

Received: March 25, 2008

Review: May 29, 2008

Accepted: June 27, 2008

How to cite this article

Brito MVH, Cunha ICC, Aragón MG, Braga TGM, Lima FD. Effects of blood storage on ice in biochemical and arterial blood gas analysis of rats. Acta Cir Bras. [serial on the Internet] 2008 Sept-Oct;23(5). Available from URL: http://www.scielo.br/acb

*Color figures available from www.scielo.br/acb 